\section{Cadmium influences the 5-fluorouracil cytotoxic effects on breast cancer cells}

\author{
Y. Asara, ' J.A. Marchal, ${ }^{2}$ P. Bandiera, ${ }^{1}$ \\ V. Mazzarello, ${ }^{1}$ L.G. Delogu, ${ }^{3}$ \\ M.A. Sotgiu, ${ }^{1}$ A. Montella, ${ }^{1}$ \\ R. Madeddu ${ }^{1,4}$ \\ 'Department of Biomedical Sciences, \\ University of Sassari, Italy \\ 2Department of Human Anatomy and \\ Embriology, University of Granada, Spain \\ ${ }^{3}$ Department of Drug Sciences, University \\ of Sassari, Italy \\ ${ }^{4}$ National Institute of Biostructures and \\ Biosystems, Rome, Italy
}

\section{Abstract}

The aim of the research was to evaluate a heavy metal, cadmium (Cd), which was used to produce alterations in human breast cancer cell line MCF-7. Moreover, we analyzed both immunohistochemical and ultrastructural alterations induced by the antineoplastic drug, 5-fluorouracil (5-FU), after exposure to different concentrations of cd. Also, we compared the effects of these compounds on actin and tubulin cytoskeleton proteins. Under ultramicroscopic observation, control cells looked polymorphous with filopodia. In cells already treated with small concentrations of $\mathrm{Cd}$, after brief times of incubation, we observed an intense metabolic activity with larger, clearer, and elongated mitochondria characterized by thin and numerous dilated cristae. 5-FU-treated cells showed cytotoxicity signs with presence of pore-like alterations in the cell membrane and evident degeneration of cytoplasm and cell nuclei. The addition of 5 -FU $(1.5 \mu \mathrm{M})$ to the cells treated with $\mathrm{Cd}(5 \mu \mathrm{M}-20 \mu \mathrm{M})$ did not induce significant ultrastructural changes in comparison with cells treated only with $\mathrm{Cd}$. In $\mathrm{Cd}+5 \mathrm{FU}$-treated cells mitochondria with globular aspect and regular cristae indicated the active metabolic state. In cells treated only with $\mathrm{Cd}$ we observed alterations in actin distribution, while tubulin branched out throughout the cytoplasm. With the association of $\mathrm{Cd}+5 \mathrm{FU}$, we observed less morphological alterations in both tubulin and actin cytoskeleton proteins. Although the mechanism remains unknown at present, our findings suggest that Cd prevents the cytotoxic effect of 5-FU on breast cancer cells. These preliminary results could have an important clinical application in patients with breast cancer.

\section{Introduction}

Cadmium (Cd) is one of the most toxic transition metals associated with air and water pollution, as well as cigarette smoking. The increase of industrialization and human activities have led to a greater use of metals, and, as a result; growing ecodispersion which involves considerable economic and social consequences. It is dangerous for human health. The absorption in the human organism occurs mainly through inhalation, ingestion and cutaneous contact. Cd has a long biological half-time; its values have been seen ranging from 15 to 40 years with an average around the 20-25 years. It is mainly accumulated in liver and kidneys.

Cd is considered to be one of the most dangerous metals, especially for human health, due to its teratogenic and carcinogenic effects. ${ }^{1}$ Indeed, there is increasing evidence demonstrating the, in vivo and in vitro, carcinogenicity of $\mathrm{Cd}$, in both human and experimental animal models.,3 The heavy metal $\mathrm{Cd}$ has been described to possess estrogenin-like activity, as an endocrine disruptor. ${ }^{4}$ Moreover, in some countries it has been used in the past, and is still now, as a contaminant in pesticides and in fungicides. Unlike the inhalation of tobacco smoke ${ }^{5}$ representing the main source of non-occupationally exposed adult subjects, ${ }^{6,7}$ the metal is vaporized during combustion. Nevertheless, the main cause of exposure to $\mathrm{Cd}$ is through food ingestion ${ }^{8,9}$ For example, the highest Cd concentrations, compared to other foods, are seen in sea food (molluscs), and kidney and liver of mammals. . $^{10-12}$

The International Agency for Research on Cancer (IARC) has classified Cd as a category 1 carcinogenic substance. ${ }^{2,13}$ Thus, the metal could induce liver cancer, hematopoietic cells neoplasm, bladder and stomach cancers. ${ }^{14}$ It is also believed that Cd may have a role in the origin of pancreatic carcinoma. ${ }^{2}$

Breast cancer is the most prevalent cancer among women in many industrialized countries. ${ }^{3,15-18}$ The MCF-7 human breast cancer cell line has been used as an excellent experimental model ${ }^{19,20}$ to improve the efficiency of different therapies before they are used on patients. The MCF-7 cell line is a useful cell line that can be used in many cancer researches and it is also an estrogen receptor-negative. ${ }^{4,21}$ The case of glandular epithelial cells is important in the estrogen hormones study and in the parallel study of the cadmium-estrogens relationship due to the ability of Cd to mimic the effects of estrogen receptors tricking the cell membrane. ${ }^{21,22}$

The fluoropyrimidines, especially the 5-fluorouracil (5-FU), are antimetabolite inhibitors of de novo purine and pyrimidines synthe-
Correspondence: Dr. Roberto Madeddu, Dipartimento di Scienze Biomediche, Istologia, Università di Sassari, viale San Pietro 43/B, 07100 Sassari, Italy.

Tel. +39.070.228569 - Fax: +39.070 .9228569$ E-mail: rmadeddu@uniss.it

Key words: cadmium, 5-Fluorouracil, MCF-7 cells

Received for publication: 20 July 2011.

Accepted for publication: 29 November 2011.

This work is licensed under a Creative Commons Attribution NonCommercial 3.0 License (CC BYNC 3.0).

CC Copyright Y. Asara et al., 2012

Licensee PAGEPress, Italy

European Journal of Histochemistry 2012; 56:e1 doi:10.4081/ejh.2012.e1

ses. $^{23,24} 5$-FU plays an important role in standard chemotherapy protocols for a range of solid tumors, including breast and colorectal cancers. ${ }^{20,21}$ Considering the carcinogenic and mutagenic effects of $\mathrm{Cd}$ on healthy living cells, it seems beneficial to use a cancer cellular line, such as MCF-7. ${ }^{3}$ It is particularly resistant to harmful solicitations of toxic metals, which provoke alterations to both cytoplasmic organelles and cytoskeleton proteins of different cellular lines. ${ }^{24-26}$ We investigated the potential antagonists effects of the antineoplastic drug 5-FU, using scanning electron microscopy (SEM), transmission electron microscopy (TEM) and immunofluorescence. The study of the modifications of cytoskeleton proteins is a parameter particularly indicative of the cellular and apoptotic cycle of the cellular lines. Cytoskeleton has been shown to be involved in the traffic of a number of membrane proteins. The effects of 5 -FU were studied on MCF-7 cultured cells exposed to different concentrations of $\mathrm{Cd}$, and, then, we evaluated the resulting morphological alterations, even at the ultrastructural level. Moreover, in order to clarify the mechanism of both $\mathrm{Cd}$ and 5-FU activities, we compared the effects of these elements on actin and tubulin, two cytoskeleton proteins, responsible not only for the intracellular transport of vesicles and cell organelles, but for their positioning and cellular integrity as well.

\section{Materials and Methods}

\section{Cell culture}

Human breast cancer MCF-7 cells were cultivated in Dulbecco's Modified Eagle's Medium (DMEM) (Gibco) supplemented with 10\% of fetal bovine serum (FBS) (Gibco), $2.0 \mathrm{mmol} / \mathrm{L}$ glutamine, $100 \mathrm{U} / \mathrm{mL}$ penicillin, and 100 
$\mathrm{mg} / \mathrm{mL}$ streptomycin. Cells were grown at $37^{\circ} \mathrm{C}$ in an atmosphere containing $5 \% \mathrm{CO}_{2}$, then expanded for several days to become confluent in T75 flasks for cellular culture. They were then treated with Trypsin-EDTA (Invitrogen) and plated in a 24-well plate for immunohistochemistry and SEM preparation, and in T75 bottles for TEM preparation.

\section{Drugs and drug treatments}

Cells were treated with 5-FU and Cadmium Chloride (CdCl2), purchased from SigmaAldrich. The drugs were dissolved in DMSO or water and stored at $-20^{\circ} \mathrm{C}$. For each experiment, the stock solutions were further diluted to obtain the desired concentrations. The final solvent concentration in cell culture was = $0.1 \% \mathrm{v} / \mathrm{v}$ of DMSO, a concentration without effect on cell replication. Parallel cultures of cells in medium with DMSO were used as controls.

\section{Cytotoxicity assays in vitro}

The effect of anticancer drugs on cell viability was assessed using the sulforhodamine-B colorimetric assay. Aliquots of MCF-7 cells suspension $\left(1 \times 10^{3}\right.$ cells/well $)$ were seeded onto 24 -well plates and incubated for $24 \mathrm{~h}$. The cells were then treated with different concentrations of drugs in the culture medium. Three days later, the wells were aspirated, fresh medium and treatment was added, and the cells were maintained for an additional three days. ${ }^{27}$ Thereafter, the cells were processed as described previously, using a Titertek Multiscan apparatus (Flow, Irvine, CA, USA) at $492 \mathrm{~nm}$. We evaluated linearity of the SRB assay with cell number for each cell line before each cell growth experiment. The $\mathrm{IC}_{50} \mathrm{val}-$ ues were calculated from semi logarithmic doseresponse curves by linear interpolation. All of the experiments were plated in triplicate wells and were carried out at least twice. For each of the experiments we used different concentrations and at different time points (Table 1).

\section{Electron microscopy}

MCF-7 cells were treated with $\mathrm{Cd}(5 \mu \mathrm{M}, 20$ $\mu \mathrm{M}, 40 \mu \mathrm{M})$ and 5 -FU $(1.5 \mu \mathrm{M})$ at different time points $(24 \mathrm{~h}, 48 \mathrm{~h})$ (Table 1$)$. The cells pellet, to be observed by TEM, were fixed in a $2 \%$ glutaraldehyde solution in a $0.1 \mathrm{M}$ cacodylate buffer $(1 \mathrm{~h})$, and washed three times, $15 \mathrm{~min}$ each, in the same buffer. Cells post-fixation was done with $1 \%$ osmium tetroxide $\left(\mathrm{OsO}_{4}\right)(1 \mathrm{~h})$, washed again in buffer and distilled water, and then embedded in $1.5 \%$ low-melting-point agarose. Small blocks (1 mm x $1 \mathrm{~mm}$ ) were cut out after the agarose had solidified. After dehydration by graded ethanol, the blocks were embedded in Spurr's low-viscosity resin. After ultra thin sections were prepared by the LKB- 8800 ultratome, with $4 \%$ uranyl acetate and lead citrate, the samples were stained. Photographic images were examined using a Zeiss 902 electron microscope at $80 \mathrm{kV}$. Culture cells, grown on circular coverslip, were fixed in $2.5 \%$ glutaraldehyde solution in phosphate buffer saline (PBS) for $90 \mathrm{~min}$, then washed three times for 5 min each in PBS, and post-fixed in $1 \% \mathrm{OsO}_{4}$ for $2 \mathrm{~h}$. After three washes, 5 min each in PBS, the samples were dehydrated through graded alcohol solutions, air-dried with hexamethyldisilazane ${ }^{28,29}$ (10 min), examined under an ESEM (environmental scanning electron microscope), and photographed in low vacuum using both SEM FEI Inspect S and Quanta 200.

\section{Immunohistochemistry}

Confluent cells were treated with trypsinEDTA (Sigma-Aldrich) and plated on round coverslips $(12 \mathrm{~mm})$ in 24-well culture plates. We incubated them for 24 and $48 \mathrm{~h}$, after which an additional concentration of $\mathrm{Cd}(5 \mu \mathrm{M}, 20 \mu \mathrm{M}, 40$ $\mu \mathrm{M})$ and 5-FU (1.5 $\mu \mathrm{M})$ (Table 1) was added. After fixation with formaldehyde $4 \%$, membrane permeabilization with Triton $0.2 \%$, and saturation with BSA $1 \%$, the cells were incubated for $1 \mathrm{~h}$ with a monoclonal anti-tubulin (SigmaAldrich), and then conjugated with Ab antimouse FITC (Sigma-Aldrich). In order to study actin, we incubated cells with TRITC-phalloidin conjugated (Sigma-Aldrich). The nuclei were observed by DAPI, and finally the coverslips, mounted by Mowiol on an object slide were studied using fluorescence microscopy Olympus BX61 (objective UplanApo 100x/1,35oil/iris, objective UplanApo 40x/0, 75) with digital B/W camera FViewII (Soft Imaging System), and analyzed by Cell software (CELL^P ver 1.20 Soft Imaging System, Olympus Soft Imaging Solution GmbH, Munster, Germany).

\section{Results}

\section{Cytotoxicity asssay}

To evaluate the cytotoxicity of $\mathrm{Cd}$ and 5-FU human breast cancer cell line MCF-7 we used the $\mathrm{SRB}$ staining method. $\mathrm{IC}_{50}$ values, defined as the drug concentration resulting in $50 \%$ loss of cell viability relative to the untreated cells, were determined for the compound. The IC50 value for $\mathrm{Cd}$ was $5 \pm 0.25 \mu \mathrm{M}$ and for 5 -FU $1.5 \pm 0.3 \mu \mathrm{M}$.

\section{Electron microscopy}

TEM analysis showed that control MCF-7 breast cancer cells were polymorphous. The centrally placed nucleus showed indentation, usually contained one or two prominent nucleoli, and possessed an evident nuclear membrane. The cytoplasmic organelles appeared well defined and possessed a large number of mitochondria with globular aspect and lamellar cristae. Furthermore, the cell surface was characterized by a high microvillus density. SEM showed a variety of elongated and polygonal shaped cells with numerous slender and thick cytoplasmic projections and an increased number of filopodia (Figure $1 \mathrm{a}, \mathrm{b}, \mathrm{c}$ ).

Table 1. Time and concentrations of experimental conditions.

\begin{tabular}{lll} 
& Concentrations & Tlime point \\
Ctrl & - & $24 \mathrm{~h}, 48 \mathrm{~h}$ \\
$\mathrm{Cd}$ & $5 \mu \mathrm{M} / 20 \mu \mathrm{M} / 40 \mu \mathrm{M}$ & $24 \mathrm{~h}, 48 \mathrm{~h}$ \\
\hline $5-\mathrm{FU}$ & $1.5 \mu \mathrm{M}$ & $24 \mathrm{~h}, 48 \mathrm{~h}$ \\
$\mathrm{Cd}+5-\mathrm{FU}$ & $\mathrm{Cd} 5 \mu \mathrm{M} / \mathrm{Cd} 20 \mu \mathrm{M}+$ & $24 \mathrm{~h}, 48 \mathrm{~h}$ \\
& $5-\mathrm{FU} 1.5 \mu \mathrm{M}$ & \\
\hline
\end{tabular}
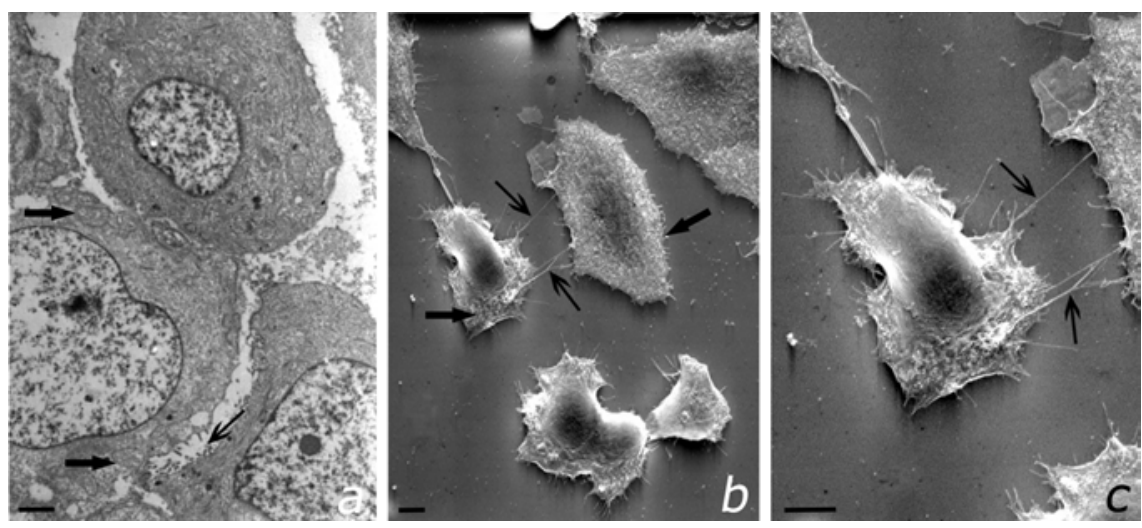

Figure 1. a) TEM 3000X, MCF-7 control; the cells, with polymorphous aspect, present numerous globular mitochondria with lamellar cristae (big arrow) and microvilli (thin arrow); b) SEM 3000X, MCF-7 control; the cells with polymorphous cytoplasm, are rich in microvilli (big arrow) and long filopodia (thin arrow); c) detail of b), MCF-7 control, the filopodia (thin arrow) are evident. Scale bar: $5 \mu \mathrm{m}$. 


\section{Cadmium}

Cd-treated cells at low concentration $(5 \mu \mathrm{M})$ and for short times of incubation (24 h) showed an intense metabolic activity with larger, clearer and globular mitochondria characterized by thin and numerous dilated cristae.

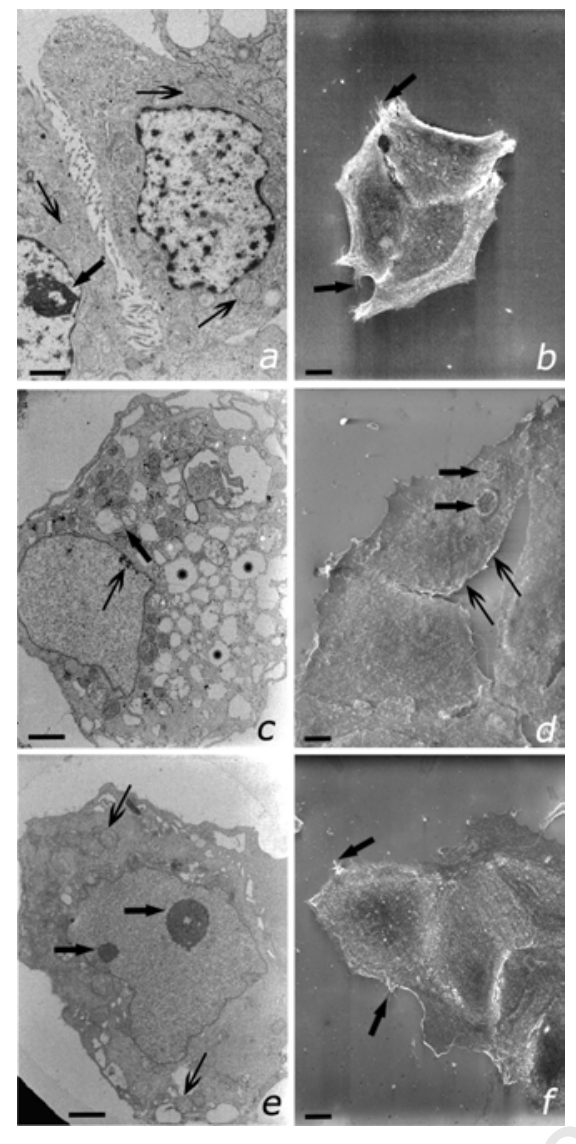

Figure 2. TEM, a) 3000X, MCF-7+Cd 5 $\mu \mathrm{M}-24 \mathrm{~h}$ the cellular nucleus is indented with dispersed chromatin and a peripheral nucleolus (big arrow), in the cytoplasm are evident numerous mitochondria with dilated cristae (thin arrow); b) SEM $3000 \mathrm{X}$, MCF-7+Cd $5 \mu \mathrm{M}-24 \mathrm{~h}$; some microvilli exhibit some prolongations of great dimensions (big arrow); c) TEM $3000 X$, MCF-7+5-Fu $1.5 \mu \mathrm{M}-24 \mathrm{~h}$; in the cytoplasm are evident numerous clear vesicles $\left.{ }^{*}\right)$, swollen mitochondria with a number of condensed cristae (big arrow); in the nucleus there are little areas of heterochromatin close to the membrane (thin arrow);

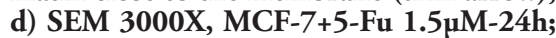
the cells show alterations on the membrane (big arrow); zones of detachment from the coverslip (thin arrow) also are seen; e) TEM $3000 \mathrm{X}$, MCF-7+Cd 20 $\mu \mathrm{M}+5-\mathrm{Fu} 1.5 \mu \mathrm{M}-24 \mathrm{~h}$; the cell shows an indented nucleus with two nucleoli (big arrow) and mitochondria with globular aspect (thin arrow); f) SEM 3000X, MCF$7+$ Cd $20 \mu \mathrm{M}+5-\mathrm{Fu} 1.5 \mu \mathrm{M}-24 \mathrm{~h}$; the cells, with fairly regular contours, present short and thin prolongations (big arrow). Scale bar: $5 \mu \mathrm{m}$.
Additionally, a large number of glycogen deposits in clusters were found. The nuclei of all the cells contained completely dispersed chromatin and one or two large nucleoli, which were peripherally located (Figure $2 a$ ). The surface of Cd-treated cells at low concentrations observed under SEM looked similar to the surface of the control cells, displaying short and abundant microvilli and infrequent blebs (Figure 2b). At high concentrations of $\mathrm{Cd}$ (20 $\mu \mathrm{M})$ and $24 \mathrm{~h}$ of treatment, the nuclei became very evident, and moved sideways in the cellular membrane. Numerous cytoplasmic vesicles were seen, including abundant mitochondria with lamellar cristae sometimes altered. The vesicles were close to the plasmalemma and showed signs of exocytosis. We observed a reduction of the superficial filopodia, although, under extreme conditions (Cd 40 $\mu \mathrm{M}, 48 \mathrm{~h}$ ), they increased significantly in number and showed an increase of cellular death. Furthermore, numerous blebs of different sizes were noticed and cells became more rounded and less attached to the dish.

\section{5-FU}

5-FU induced cytotoxicity in MCF-7 cells showed, cytoplasmic alterations, an increased number of distended vesicles appearing, and swollen mitochondria with partial crista loss. Components of cell nuclei displayed evident signs of degeneration. There was an absence of nucleoli, and the chromatin condensed into dense granules located near the nuclear membrane (Figure 2c). SEM analyses showed that 5-FU-treated cells had lengthened, became more irregular, and there were numerous intercellular spaces. However, the most striking feature was the pore-like alterations in the cell membrane, which were absent in both parental MCF-7 cells and Cd-treated cells. Also, we observed cells more rounded and less attached to the dish (Figure 2d).

\section{Cadmium plus 5-FU}

The addition of 5-FU to cells treated with $\mathrm{Cd}$ (5-20 $\mu \mathrm{M})$ did not induce significant ultrastructural changes compared with cells treated only with $\mathrm{Cd}$. In cells treated with $\mathrm{Cd} 40 \mu \mathrm{M}$, the cellular death increased. In Cd+5FU-treated cells, numerous mitochondria with globular aspect and regular cristae were present. The nucleus was regular in shape with dispersed chromatin and one or two nucleoli. These observations indicate a cell system in an active metabolic state. SEM analyses showed flat cells with short filopodia (Figure 2 e,f), that after 48 $\mathrm{h}$ of treatment were made shorter and tended to disappear.

\section{Immunohistochemistry}

In control cells both tubulin and actin appeared distributed in the cytoplasm showing
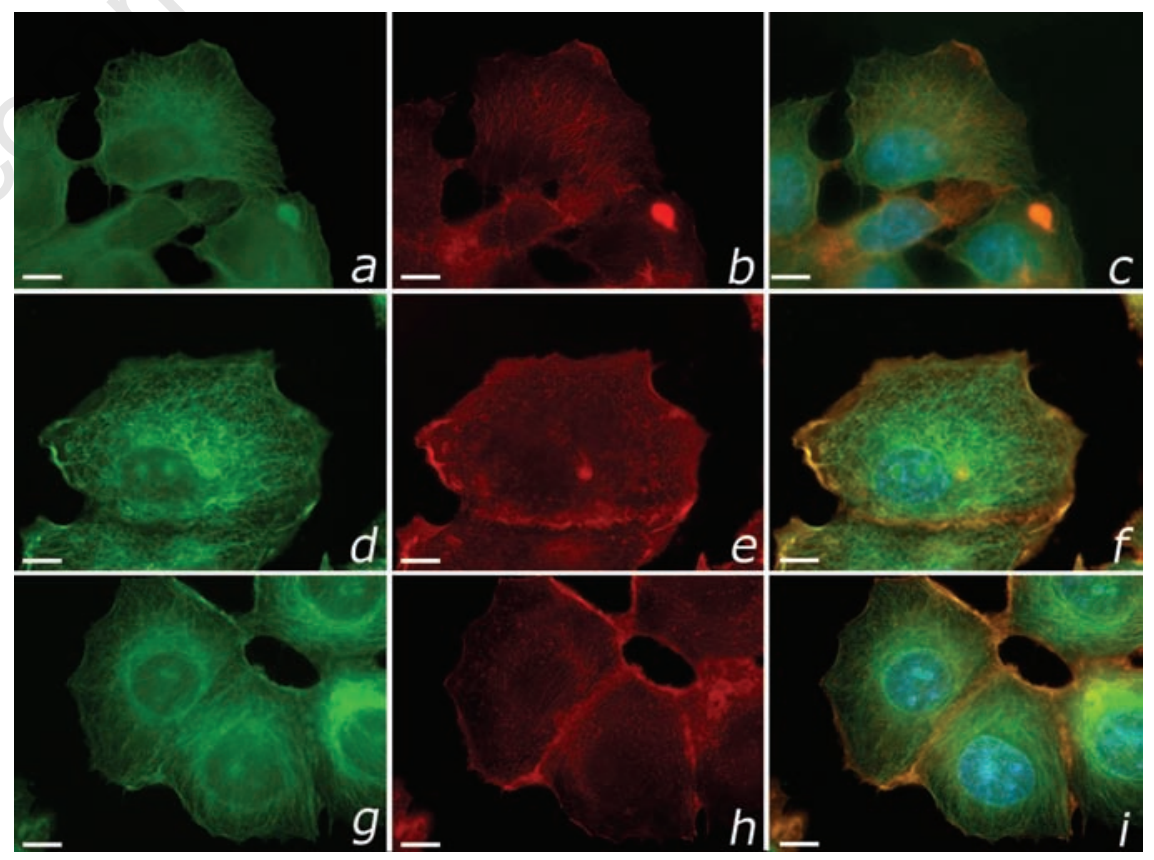

Figure 3. MCF-7 100X: a,b,c) control (tubulin-FITC, phalloidin-TRITC, Merge) tubulin and actin are organized in filamentous structures and are regularly distributed in the cytoplasm; d,e,f) Cd $5 \mu$ M-24h (FITC, TRITC, Merge); g,h,i) Cd $20 \mu \mathrm{M}-48 \mathrm{~h}$ (FITC, TRITC, Merge); tubulin is mainly distributed in the nucleus and cytoplasm; actin is constituted by big bundles of filaments and smeared patche. Scale bar: $5 \mu \mathrm{m}$. 
a well-organized filamentous structure (Figure 3 a,b,c).

\section{Cadmium}

In cells treated with $\mathrm{Cd}(5 \mu \mathrm{M}$ and $20 \mu \mathrm{M})$ for $24 \mathrm{~h}$, tubulin did not undergo structural changes; it remained quite distributed in the nuclear and cytoplasmatic zone (Figure 3 d,e,f,g,h,i). After treatment with $\mathrm{Cd}$ the fine architecture of actin filaments appeared changed, consisting of large bundles of filaments which, in some points, thickened to form smeared patches. This finding was quite similar to that observed after incubation with Cd $5 \mu \mathrm{M}$ (Figure $3 \mathrm{~d}, \mathrm{e}, \mathrm{f}$ ) and became more pronounced with $\mathrm{Cd} 20 \mu \mathrm{M}$. High concentrations of $\mathrm{Cd}$ induced a strong, evident, actin expression in the plasmatic membrane. Tubulin, especially in MCF-7 cells treated with Cd 20 $\mu \mathrm{M}$, appeared with an intense perinuclear and compact fluorescence from which separate arrays of filaments departed, branching out throughout the cytoplasm (Figure $3 \mathrm{~g}, \mathrm{~h}, \mathrm{i}$ ). Cells treated with $\mathrm{Cd} 40 \mu \mathrm{M}$, as already said, showed a cellular death increase.

\section{5-FU}

In 5-FU-treated cells actin appeared less organized and filamentous. Tubulin filaments showed a regular halo of labeling around the nuclear membrane that did not spread into the cytoplasm. The times of incubation of 24 and $48 \mathrm{~h}$ did not show substantial differences (Figure $4 \mathrm{a}, \mathrm{b}$ ).

\section{Cadmium plus 5-FU}

In Cd $(5 \mu \mathrm{M}-20 \mu \mathrm{M})+5$-FU-treated cells for $24 \mathrm{~h}$ actin expression was less filamentous compared to parental non-treated cells; nevertheless, the distribution was clearly better than in the Cd-only-treated cells. Tubulin showed expression and distribution patterns similar to those seen in control and Cd-treated cells (Figure $4 \mathrm{~d}, \mathrm{e}, \mathrm{f}$ ). In cells treated for $48 \mathrm{~h}$ with $\mathrm{Cd}$ $(5 \mu \mathrm{M}-20 \mu \mathrm{M})+5 \mathrm{FU}$, actin was progressively breaking, whereas tubulin maintained a stable and ordered structure (Figure $4 \mathrm{~g}, \mathrm{~h}, \mathrm{i}$ ). Therefore, the association $\mathrm{Cd}+5-\mathrm{FU}$ induced less alterations in both actin and tubulin proteins. Under extreme conditions ( $\mathrm{Cd} 40 \mu \mathrm{M}, 48$ h), the addition of 5-FU did not significantly modify the cellular disorder observed with only Cd.

\section{Discussion}

Cadmium is a heavy metal present in the environment with proven carcinogenic effects on several organs including lung, liver, kidneys and prostate, among others. ${ }^{2}$ The damaging effects in the cytoskeleton bring about a complete disappearance of microtubules ${ }^{30}$ and the disruption of the filamentous actin protein. ${ }^{31}$ The action of $\mathrm{Cd}$ on the proliferation of MCF-7 breast cancer cell line has been proved. ${ }^{32}$ Yet, 5 -FU is an antitumor drug, with an important role in standard chemotherapy protocols, for a range of solid tumors including breast cancer and colorectal cancers. ${ }^{33}$

Our results demonstrated that in the cells treated only with $\mathrm{Cd}$, there are ultrastructural changes in MCF-7 cells, including the appearance of secretive vacuoles in the cellular cytoplasm, probably lysosomes. Cells can produce these vesicles as a response to the exposure to $\mathrm{Cd}$. The increase of lysosomes after exposure of $\mathrm{Cd}$ is known as a mechanism of sequestration and excretion of substances taken up by cells from the environment. ${ }^{14}$ Moreover, Cd induced mitochondrial swelling with a dense matrix in comparison to control non-treated MCF-7 cells, which presented globular mitochondrial with regular lamellar cristae. In breast cancer cells it can be supposed that, besides the implication of mitochondria in phenomena of oxidative stress; ${ }^{34}$ the morphological alterations of membranes being a possible consequence of variations in transcription and, consequently, transduction to the block of metallothionein. ${ }^{35}$

Moreover, in Cd-treated cells, nuclei were usually moved toward the cellular membrane and a large number of vesicles and organelles were present from the opposite part of the cell. Actin filaments were arranged as big bundles in the cytoplasmic membrane, while the tubulin branched out throughout the cytoplasm. All of this would explain the perimembranous position of the nucleus. ${ }^{26}$ It has been demonstrated that $\mathrm{Cd}$ increases proliferation in MCF7 breast cancer cells and disrupt the normal cell homeostasis triggering signals otherwise switched off. ${ }^{36}$

5-FU-treated cells displayed characteristic signs of degeneration in both cytoplasm and nucleus such as the lack of membrane integrity and the appearance of exocytotic bodies. Moreover, an increased rate of spherical and non-adherent cells was present after treatment with a high dose of 5-FU. These effects indicate the anticancer properties of the antimetabolite 5-FU, which acts hindering the cellular growth and increasing the secretion of vesicles of lysosomal nature. ${ }^{37}$ Combined treatment of $\mathrm{Cd}$ and 5-FU did not alter ultrastructural components showing similar characteristics to MCF-7 cells, which were only treated with $\mathrm{Cd}$, independently of 5 -FU dose. We observed that the tubulin aspect is comparable to control non-treated cells and that the actin presents a non- filamentous organization like in Cd-treated cells. These results suggest that $\mathrm{Cd}$ pre-
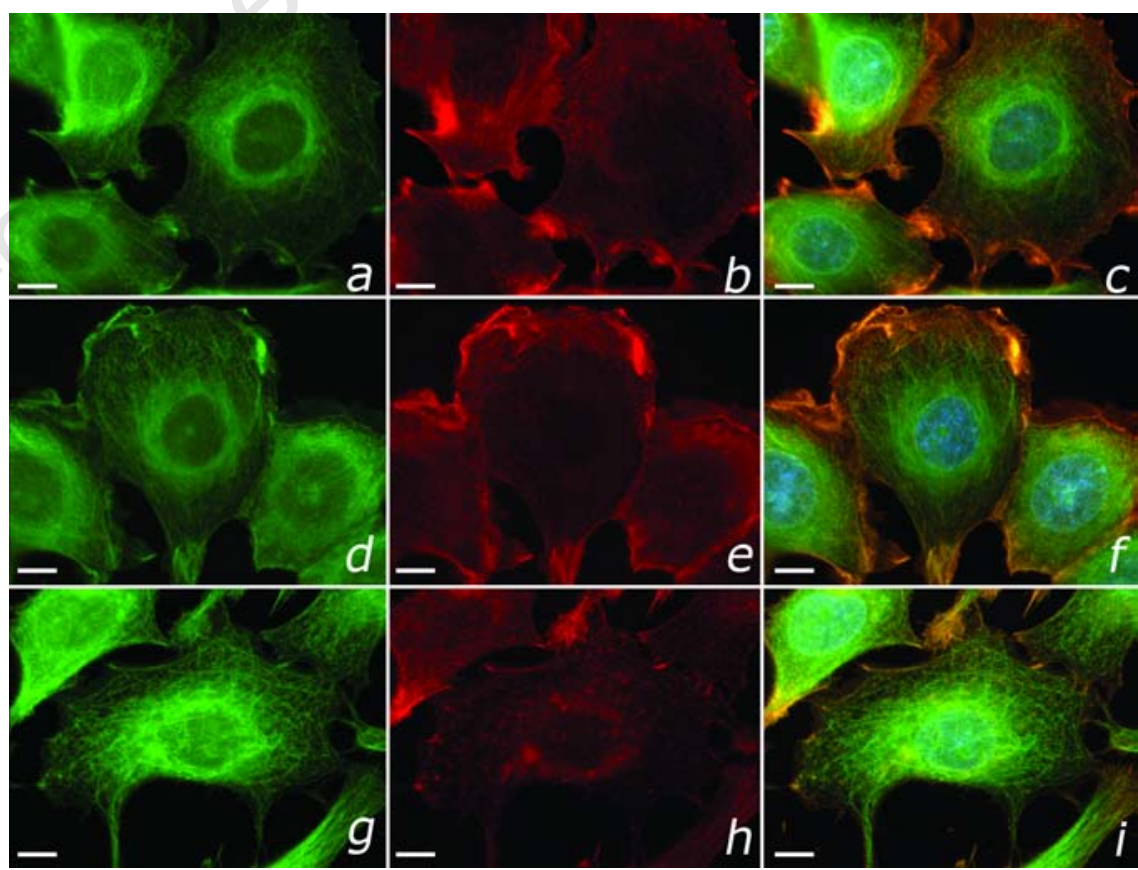

Figure 4. MCF-7 100X: a,b,c) 5-FU 1.5uM-48h (FITC, TRITC, Merge) actin is less organized and filamentous then $\mathrm{Ctrl}$, tubulin shows a regular halo of labelling around the nuclear membrane; d,e,f) Cd 5uM + 5-FU 1.5uM-24h (FITC, TRITC, Merge); actin is less filamentous, although its distribution looks better improved than in the Cd-onlytreated cells; tubulin has a distribution patterns similar to that of control and Cd-treated cells; g,h,i) Cd $20 \mu \mathrm{M}+5-\mathrm{FU} 1.5 \mu \mathrm{M}-48 \mathrm{~h}$ (FITC, TRITC, Merge) actin is progressively breaking, whereas tubulin maintains a stable and ordered structure. Scale bar: $5 \mu \mathrm{m}$. 
vents the anticancer effects of 5-FU. This blockage acts preventing the formation of lysosomes in the cytoplasm, that is in relationship with oxidized stress at mitochondrial level. ${ }^{35,38}$ With the combination $\mathrm{Cd}+5 \mathrm{FU}$ there are few and small number of lysosomal vesicles.

In conclusion, in the present study we demonstrated the importance of the interaction between the heavy environmental metal Cadmium, and the antitumor drug 5-FU from a morphological point of view. Although the mechanism remains unknown at present, our findings suggest that Cd prevents the cytotoxic effect of 5-FU on breast cancer cells. Further research is required to fully analyze correlations between our morphological results and the bimolecular aspects involved in this phenomenon.

Our results suggest the study of patients exposed to environmental pollution, including cigarette smoke, and treated with chemotherapy with the determination of cadmium levels in breast cancer patients with negative estrogen receptor before 5 -FU treatment, in order to highlight a possible interaction in vivo between $\mathrm{Cd}$ and anticancer drugs.

\section{References}

1. Waalkes MP, Rehm S, Riggs CW, Bare RM, Devor DE, Poirier LA et al. Cadmium carcinogenesis in male Wistar rats: doseresponse analysis of tumor induction in the prostate and testes and at the injection site. Cancer Res 1988; 48:4656-63.

2. Waalkes MP. Cadmium carcinogenesis. Mutat Res 2003;533:107-20.

3. Chiber R. and Ord M. Cadmium-induced multistep transformation of cultured Indian muntjac skin fibroblast. Bio Metals 1990; 3:213-221.

4. Byrne C, Divekar SD, Storchan GB, Parodi DA, Martin MB. Cadmium - A metallorhormone? Toxicology and Applied Pharmacology 2009;238:266-71.

5. Nadkarni RA. Some considerations of metal content of tobacco products. Chem Ind 1974; 7:693-6.

6. Lewis GP, Coughlin L, Jusko W, Hartz S. Contribution of cigarette smoking to cadmium accumulation in man. Lancet 1972;1:291-2.

7. Madeddu R, Muresu E, Montella A, Chessa G, Cherchi GB, Piras P et al. Low Cadmium concentration in whole blood from residents in Northern Sardinia (Italy) with special reference to smoking habits. JPMH 2009;50:46-52.

8. Moy G, Käferstein F, Kim YM , Motarjemi Y, Quevedo F. Dietary exposure to lead, cadmium, mercury and polychlorinated biphenyls. Arch Lebensmittelhyg 1993;44: 45-51.

9. Oskarsson A, Widell A, Olsson IM, Grawé KP. Cadmium in food chain and health effects in sensitive population groups. Biometals 2004;17:531-4.

10. Falcó G, Llobet JM, Bocio A, Domingo JL. Daily intake of arsenic, cadmium, mercury, and lead by consumption of edible marine species. J Agric Food Chem 2006;54:6106-12.

11. Sirot V, Guérin T, Volatier JH, Leblanc JC. Dietary exposure and biomarkers of arsenic in consumers of fish and shellfish from France. Sci Total Environ 2009;407: 1875-85.

12. Galal-Gorchev H. Dietary intake, levels in food and estimated intake of lead, cadmium and mercury. Food Add Contam 1993; 10:115-128.

13. Benbrahim-Tallaa L, Tokar EJ, Diwan BE, Dill AL, Coppin JF, Waalkes MP. Cadmium malignantly transforms normal human breast epithelial cells into a basal-like phenotype. Environ Health Perspect 2009; 17:1847-52.

14. Asar M, Kayisli UA, Izgut-Uysal V.N, Akkoyunlu G. Immunohistochemical and ultra structural changes in the renal cortex of cadmium-treated rats. Biol Trace Elem Res 2004;97:249-63.

15. Antila E, Mussalo-Rauhamaa H, Kantola M, Atroshi F, Westermarck T. Association of cadmium with human breast cancer. Sci Total Environ 1996;186:251-6.

16. Shimoda R, Nagamine T, Takagi H, Mori M, Waalkes MP. Induction of apoptosis in cells by cadmium: quantitative negative correlation between basal or induced metallothionein concentration and apoptotic rate. Toxicol Sci 2001;64:208-15.

17. Jin YH, Clark AB, Slebos RJ, Al-Refai H, Taylor JA, and Kunkel TA et al. Cadmium is a mutagen that acts by inhibiting mismatch repair. Nat Genet 2003;34:326-9.

18. Lukyanova NYu, Rusetskya NV, Tregubova NA, Chekhun VF. Molecular and cell cycle in MCF-7 cells resistant to cisplatin and doxorubicin. Exp Oncol 2009;31:87-91.

19. Marchal JA, Boulaiz H, Suarez I, Saniger I, Campos J, Carillo E et al. Growth inhibition, G1-arrest, and apoptyosis in MCF-7 human breast cancer cells by novel highly lipophilic 5-fluorouracil derivatives. Invest New Drugs 2004;22:379-389.

20. Marchal JA, Rodríguez-Serrano F, Caba 0, Aránega A, Gallo MA, Espinosa A et al. Antiproliferative activity, cell-cycle dysregulation, and cellular differentiation: salicyl- and catechol-derived acyclic 5-fluorouracil $0, \mathrm{~N}$-acetals against breast cancer cells. Chem Med Chem 2007;2:1814-21.

21. Johnson MD, Kenney N, Stoica A, Hilakivi-
Clarke L, Singh B, Chepko G et al. Cadmium mimics the in vivo effects of estrogen in the uterus and mammary gland. Nature Medicine 2003;9:1081-4.

22. Kovala-Demertzi D, Staninska M, GarciaSantos I, Castineiras A, Demertzis MA. Synthesis, crystal structures and spectroscopy of meclofenamic acid and its metal complexes with manganese (II), copper (II), zinc (II) and cadmium (II). Antiproliferative and superoxide dismutase activity. J Inorg Biochem 2011;105: 1187-95.

23. Marchal JA, Nunez MC, Suarez I, DiazGavilàn M, Gomez-Vidal JA, Boulaiz H et al. A synthetic uracil derivative with antitumor activity through decreasing cyclin D1 and Cdk1, and increasing p21 and p27 in MCF-7 cells. Breast Cancer Res Treat 2007;105:237-46.

24. De Pasquale J. Rearrangement of the F.Actin cytoskeleton in estradiol-treatred MCF-7 breast carcinoma cells. Histochem Cell Biol 1999; 112:341-350.

25. Ehlers EM, Schubert C. Differences in morphology and cytoskeleton of MCF-7 and Mx-1 cells after therapy with OH-Tamoxifen and the pure estrogen antagonist ZM 182780. Ann Anat 1999;231-6.

26. Madeddu R, Aranega A, Arena N, Malaguernera L, Marchal JA, Prados JC et al. Indirect immunofluorescence study on the cytoskeleton of normal (FG) and neoplastic (SGS/3A) cadmium treated fibroblasts. Ital J Anat Embryol 2005; 110:225-36.

27. Villalobos M, Olea N, Brotons JA, OleaSerrano MF, Ruiz de Almodóvar JM, Pedraza V. The E-Screen assay: A comparison of different MCF-7 cell stocks. Env Health Perspect 1995;103:844-9.

28. Bell SW, Master SK, Ingram P, Waters M, Shelburne JD. Ultrastructure and $\mathrm{x}$-ray microanalysis of macrophages exposed to cadmium chloride. Scan Electron Microsc 1979;(3):111-21.

29. Forge A, Nevill G, Zajic G, Wright A. Scanning electron microscopy of the mammalian organ of corti: assessment of preparative procedures. Scanning Microsc 1992;6:521-35.

30. Gerspacher C, Scheuber U, Schiera G, Proia P, Gygax D, Di Liegro I. The effect of cadmium on brain cells in culture. Int $\mathrm{J}$ Mol Med 2009; 24: 311-318.

31. Liu Y and Templeton DM. Role of the cytoskeleton in $\mathrm{Cd} 2+$-induced death of mouse mesangial cells. Can J Physiol Pharmacol 2010;88:341-52.

32. Garcia-Morales P, Saceda M, Kenney N, Kim N, Salomon DS, Gottardis MM et al. Cadmium on estrogen receptor of levels and estrogen-induced responses in human breast cancer cells. J Biol Chem 1994; 
269:16896-901.

33. Cunningham D, Coleman R. New options for outpatient chemotherapy the role of oral fluoropyrimidines. Cancer Treat Rev 2001;27:211-20.

34. Zhang Y, Li JH, Jiang FL, Tian FF, Liu Y. Spectroscopic and microscopic studies on the mechanisms of mitochondrial toxicity induced by different concentrations of cadmium. J Membr Biol 2011;241:39-49.
35. Cannino G, Ferruggia E, Luparello C, Rinaldi AM Cadmium and mitochondria. Mitochondrion 2009; :377-84.

36. Brama M, Gnessi L, Basciani S, Cerulli N, Politi L, Spera G et al. Cadmium induces mitogenic signaling in breast cancer cell by an ERalpha-dependent mechanism. Mol Cell Endocrinol 2007;264:102-8.

37. Marchal JA, Melguizo C, Prados J, Aránega $\mathrm{AE}$, Gómez JA, Campos J et al.
Modulation of Myogenic Differentiation in a Human Rhabdomyosarcoma Cell Line by a New Derivative of 5-Fluorouracil (QF3602). Jpn J Cancer Res 2000;91:934-40.

38. Cuypers A, Plusquin M, Remans T, Jozefczak M, Keunen E, Gielen $\mathrm{H}$ et al. Cadmium stress: an oxidative challenge. Biometals 2010;23:927-40. 